Article

\title{
Influences of Water Content in Feedstock Oil on Burning Characteristics of Fatty Acid Methyl Esters
}

\author{
Cherng-Yuan Lin * and Lei Ma \\ Department of Marine Engineering, National Taiwan Ocean University, Keelung 202, Taiwan; \\ awpcsawp@yahoo.com.tw \\ * Correspondence: Lin7108@ntou.edu.tw
}

Received: 15 August 2020; Accepted: 8 September 2020; Published: 10 September 2020

\begin{abstract}
Strong alkaline-catalyst transesterification with short-chain alcohol is generally used for biodiesel production due to its dominant advantages of shorter reaction time and higher conversion rate over other reactions. The existence of excess water content in the feedstock oil might retard the transesterification rate and in turn deteriorate the fuel characteristics of the fatty acid methyl esters. Hence, optimum water content in the raw oil, aimed towards both lower production cost and superior fuel properties, becomes significant for biodiesel research and industrial practices. Previous studies only concerned the influences of water contents on the yield or conversion rate of fatty acid methyl esters through transesterification of triglycerides. The effects of added water in the reactant mixture on burning characteristics of fatty acid methyl esters are thus first investigated in this study. Raw palm oil was added with preset water content before being transesterified. The experimental results show that the biodiesel produced from the raw palm oil containing a $0.05 \mathrm{wt} . \%$ added water content had the highest content of saturated fatty acids and total fatty acid methyl esters (FAME), while that containing $0.11 \mathrm{wt} . \%$ water content had the lowest content of total FAME and fatty acids of longer carbon chains than $\mathrm{C} 16$ among the biodiesel products. Regarding burning characteristics, palm-oil biodiesel made from raw oil with a $0.05 \mathrm{wt} . \%$ added water content among those biodiesels was found to have the highest distillation temperatures, flash point, and ignition point, which implies higher safety extents during handling and storage of the fuel. The added water content $0.05 \mathrm{wt} . \%$ in raw oil was considered the optimum to produce palm-oil biodiesel with superior fuel structure of fatty acids and burning characteristics. Higher or lower water content than $0.05 \mathrm{wt} . \%$ would cause slower nucleophilic substitution reaction and thus a lower conversion rate from raw oil and deteriorated burning characteristics in turn.
\end{abstract}

Keywords: burning characteristics; fatty acid methyl ester; added water content; fuel structure; distillation temperature

\section{Introduction}

Biodiesel is composed of mono-alkyl esters of long-chain fatty acids primarily produced through transesterification of vegetable oils, animal fats or microalgae lipids with short chain alcohols by virtue of nucleophilic substitution. Biodiesel has been considered a superior alternative fuel to petro-diesel due to its dominant advantages including superior biodegradability, being free of SOx emissions and acid rain, having enhanced combustion due to its higher oxygen content, exhibiting excellent lubricity, containing no carcinogenic PAHs (polycyclic aromatic hydrocarbons), etc. [1,2]. The application of biodiesel fuel could alleviate the emission of greenhouse gas $\mathrm{CO}_{2}$ owing to the lower carbon content of biodiesel by about $10 \mathrm{wt} . \%$ compared to petro-diesel. However, in comparison with diesel fuel, biodiesel has a higher kinematic viscosity and inferior low-temperature fluidity. Heating or adding adequate antifreeze would improve these characteristics of biodiesel [3]. 
International fuel specifications for biodiesel, such as ASTM D6751 and EN 14214, have been drafted to regulate fuel properties in order to protect users' equipment. Water content is a significant fuel characteristic of biodiesel. Higher water content in biodiesel will accelerate the corrosion rate of metallic engine parts [4]. Partial emulsion may be formed from accumulation of water content with liquid fuel to block the fuel feeding system [5]. During the production process of biodiesel, the water content has a dominant influence on the conversion rate of feedstock and the appearance of the saponification phenomenon.

Bitonto and Pastore [6] found that water content, acid value, and free fatty acids (FFA) of feedstock oils should be lower than $0.06 \mathrm{wt} . \%, 1 \mathrm{mg} \mathrm{KOH} / \mathrm{g}$, and $0.5 \mathrm{wt} . \%$, respectively, to prevent negative effects on the biodiesel product. Hakimi et al. [7] even suggested all reactants should be substantially anhydrous during alkali-catalyzed transesterification. Yasar [8] studied the effect of water content of the feedstock on the ester content of biodiesel. Chen et al. [9] further indicated that the upper limit of water content in raw oil is $0.05 \mathrm{wt} . \%$, for which the conversion rate of transesterification could reach above $90 \%$. The conversion rate is only $5.6 \%$ if the added water in feedstock oil is $5 \mathrm{wt} . \%$. Shi et al. [10], after investigating the effects of water content in rapeseed oil on transesterification, found that the addition of $2.5 \mathrm{wt}$.\% to the feedstock oil achieved the highest conversion rate of transesterification. They considered that the addition of an adequate amount of water enhances the hydrolysis of fatty acids. However, the free fatty acids formed from such a hydrolysis process facilitate a transesterification reaction towards biodiesel production [11].

The effects of added water contents on the types of reaction and the yields of methyl esters in transesterification of triglycerides have been widely studied. They inferred that water presence in biodiesel might cause ester hydrolysis, leading to hydrolytic and oxidative degradation and rapid growth of microorganisms. In addition, the engine performance and emission characteristics of emulsion of water-in-biodiesel were investigated previously. Zhang et al. [12] studied the effects of water addition in biodiesel emulsion on spray, combustion, and emission characteristics of a diesel engine. They found water in the emulsion might enhance micro-explosion, resulting in improving fuel-air mixing and reduction of NOx and CO emissions. Rao and Anad [13] prepared biodiesel emulsion added with 5 to $10 \mathrm{wt}$.\% water and observed lower brake thermal efficiency and higher NO emission for the emulsion than those for neat diesel. The effects of water addition in the corn-oil biodiesel on engine performance were studied by Sudalaimuthu et al. [14]. Zakaria et al. [15] experimentally found that the water contents in palm-oil biodiesels increased with the increase of storage temperatures and storage time, leading to degradation of fuel properties. Lawen et al. [16] observed that occurrence of intensive microbial activity in biodiesel might cause the increase of its water content. Delfino et al. [17] developed an alternative method of electrochemical impedance spectroscopy to determine water content in biodiesel. Although the fuel properties might be influenced by added water contents of feedstock oil, the water effects on burning characteristics of fatty acid methyl esters have not been investigated as yet in the literature [18-21]. The optimum water content for achieving superior burning characteristics of biodiesel have not been studied either. Therefore, the effects of the added water content in palm oil feedstock on the burning characteristics of a biodiesel product including the profile of fatty acid compounds, heating value, flash point, etc., were first experimentally investigated in this study. The results of this study could provide valuable references to possible audience for adopting adequate process of water removing from or adding into feedstock oils during transesterification reaction.

\section{Experimental Details}

\subsection{Preparation of Biodiesel from Palm Oil with Various Water Contents Added}

Palm oil, with water contents ranging from $0.02 \mathrm{wt} . \%$ to $0.12 \mathrm{wt} . \%$, was added and stirred by a mechanical homogenizer (Model Ultra-Turrax T50, IKA Inc., Staufen, Germany). The properties of the palm oil that were provided by the vender (Formosa Oilseed Processing Ltd. in Taichung 
City, Taiwan) are shown in Table 1 . The palm oil and water mixtures were then preheated to $60{ }^{\circ} \mathrm{C}$. Methanol was mixed with the alkaline catalyst $\mathrm{NaOH}$ using a mechanical homogenizer. The molar ratio of methanol to palm oil was set at 6 . The alkaline catalyst $\mathrm{NaOH}$ was weighted to be $1 \mathrm{wt}$. $\%$ of the palm oil. The premixed methanol and catalyst $\mathrm{NaOH}$ solution was slowly added into the preheated palm oil and water mixture and stirred using a mechanical homogenizer at a speed of $6000 \mathrm{rpm}$ to undergo transesterification for $30 \mathrm{~min}$. After the completion of the transesterification reaction, adequate amounts of glacial acetic acid were added to the product mixture to neutralize the $\mathrm{pH}$ value, and this was stirred for $1 \mathrm{~min}$. The product settled and separated to create an upper biodiesel layer and a lower glycerol layer. The biodiesel, after being removed from the glycerol layer, was heated to $70{ }^{\circ} \mathrm{C}$ for $30 \mathrm{~min}$ to vaporize any volatile impurity, such as methanol, away from the biodiesel product. The biodiesel was then water-washed with $10 \mathrm{wt}$ \% de-ionized water and settled for $15 \mathrm{~min}$ to remove the lower-layer liquid. The biodiesel was then distilled at $110{ }^{\circ} \mathrm{C}$ for $30 \mathrm{~min}$ to separate from the residual water and methanol to complete the production process.

Table 1. Properties of palm oil feedstock.

\begin{tabular}{cc}
\hline Item & Property \\
\hline Water content $(\mathrm{wt} . \%)$ & 0.029 \\
Acid value $(\mathrm{mg} \mathrm{KOH} / \mathrm{g})$ & 0.16 \\
Peroxide value $(\mathrm{meq} / \mathrm{kg})$ & 0.53 \\
Lovibond Tintometer & $\mathrm{R} 1.5 \mathrm{Y} 15$ \\
Melting point $\left({ }^{\circ} \mathrm{C}\right)$ & 23.01 \\
Specific gravity & 0.907 \\
Cold filter plugging Point $\left({ }^{\circ} \mathrm{C}\right)$ & 16 \\
\hline
\end{tabular}

\subsection{Analysis of Burning Characteristics of Fatty Acid Methyl Esters from Palm Oil with Various Water Contents}

The burning characteristics of biodiesel produced through a transesterification reaction from palm oil with various added water contents were analyzed. An optical microscope (Model BX-60, Olympus Inc., Tokyo, Japan) along with a charged-couple device, Image-Pro Plus version 4.1 analysis software (Media Cybernetics Inc., Rockville, MD, USA), and an image analyzer (Model TK-C1380, JVC Inc., Yokohama, Japan) were utilized to observe the added water droplets within the palm oil layer. The weight proportions of the fatty acids of biodiesel produced from palm oil with various water contents added were analyzed by a gas chromatograph (GC) analyzer (Model GC14A, Shimadzu Inc., Kyoto, Japan) accompanied with a Flame Ionization Detector (FID) and a chromatograph data management system (Avantech Inc., Taipei, Taiwan). The fused silica capillary column (Model Zebron ZB-5HT Inferon Column, Phenomenex Inc., Torrance, CA, USA) used in the GC analyzer was 30 min length, $0.32 \mathrm{~mm}$ in inside diameter, and $0.25 \mu \mathrm{m}$ in film thickness. Adequate type of capillary column is significant to identify fatty acid compounds. The compound of heptadecanoic acid methyl ester of $99 \%$ purity was used as the internal standard to mix with the biodiesel sample. The temperature of the injector and FID was set at $250^{\circ} \mathrm{C}$. Nitrogen gas at $20 \sim 100 \mathrm{~mL} / \mathrm{min}$ flow rate was used as the carrier gas. The retention times and elution order were used to chromatographically resolved into the types of methyl esters appeared in the biodiesel samples. The weight fraction of the corresponding fatty ester $i$ $\left(C_{i}\right)$ could be determined by the following formula:

$$
C_{i}=\frac{A_{i}}{A_{E I}}\left[\frac{C_{E I} \times V_{E I}}{m}\right]
$$

where $A_{i}$ is the peak area of the corresponding fatty acid, $A_{E I}$ is the peak area of heptadecanoic acid methyl ester, $\mathrm{C}_{\mathrm{EI}}$ and $\mathrm{V}_{\mathrm{EI}}$ are the concentration and volume of the internal standard, and $\mathrm{m}$ is the mass 
of the sample. The weight fraction of total fatty acid methyl esters can be calculated based on the following formula:

$$
\mathrm{C}=\frac{\left(\sum \mathrm{A}\right)-\mathrm{A}_{\mathrm{EI}}}{\mathrm{A}_{\mathrm{EI}}} \times \frac{\mathrm{C}_{\mathrm{EI}} \times \mathrm{V}_{\mathrm{EI}}}{\mathrm{m}} \times 100 \%
$$

where $\Sigma \mathrm{A}$ is the integrated peak areas of the fatty acid methyl esters identified in the biodiesel sample [22]. The weight percentage of longer carbon-chain fatty acids than C16 was calculated by summing up the weight percentages of those fatty acids longer than C16.

The heating value, in units of $\mathrm{cal} / \mathrm{g}$ or $\mathrm{MJ} / \mathrm{kg}$, is defined as the amount of heat released after the complete burning of a tested fuel. An oxygen bomb calorimeter (Model 1261 automatically adiabatic, Parr Inc., Demopolis, AL, USA) was used to analyze the heating value of the biodiesel sample. The specific gravity (sg) of the fuel sample at $15^{\circ} \mathrm{C}$ was measured with a hydrometer (Model 0709, Ho Yu Inc., Taoyuan City, Taiwan) placed in a graduated cylinder. The flash point and ignition point, which are two important safety indicators during fuel storage and transportation, were measured with a Pensky-Marten closed-cup flash point tester based on the ISO 3679:2015 standard method [23]. When a fuel sample is heated at some temperature to accumulate its vaporized gas concentration, a flame holder is swept over the gas environment to cause an instantaneous spark and then be distinguished. Such a temperature is termed a flash point. If the tested fuel sample is heated at some temperature to accumulate vaporizing fuel gas, the burning of the fuel sample could occur and last continuously for at least $5 \mathrm{sec}$; the ignition point was recorded for that temperature.

The distillation temperatures of the tested samples were analyzed by a distillation temperature analyzer (Model HAD-620, Petroleum Analyzer Inc., Houston, TX, USA). An ASTM D86 curve of liquid fuel for comparison can be plotted using the data for the distillation temperatures corresponding to various volumetric percentages of distilled and condensed fuel. The distillation temperature at $50 \mathrm{vol} . \%$ liquid fuel distilled, condensed, and collected is denoted as $\mathrm{T}_{50}$. The specific gravity (sg) together with the $T_{50}$ of the sample fuel can be used to calculate the cetane index (CI) of the liquid fuel [24], which indicates the time delay of compression-ignition of the sample fuel:

$$
\mathrm{CI}=-420.34+0.016 \mathrm{API}^{2}+0.192\left(\log \mathrm{T}_{50}\right)+65.01\left(\log \mathrm{T}_{50}\right)^{2}-0.0001809 \mathrm{~T}_{50}
$$

where

$$
\mathrm{API}=141.5 / \mathrm{sg}-131.5
$$

\section{Results and Discussion}

The effects of the added water content in palm oil on the burning characteristics of fatty acid methyl esters were experimentally investigated in this study. The mean values of the experimental data were recorded after at least three repetitions. The experimental uncertainties of the results were estimated based on the method by Holman [25]. The experimental uncertainties of the flash point, specific gravity, ignition point, distillation temperature, and the heating value were $\pm 1.27 \%, \pm 3.16 \%$, $\pm 2.93 \%, \pm 3.52 \%$, and $\pm 1.83 \%$, respectively. The experimental results were described and discussed in the following.

\subsection{Micrograph of Water in Palm Oil and Fatty Acid Methyl Esters (FAME)}

Palm oil with various water contents added, ranging from $0.02 \mathrm{wt} . \%$ to $0.12 \mathrm{wt} . \%$, was used as the raw oil to undergo a methanol assisted transesterification reaction with strong alkaline catalyst $\mathrm{NaOH}$. A micrograph of the added water droplets of $0.05 \mathrm{wt} . \%$ distributed within the palm oil layer captured by an optical electron microscope in conjunction with a charged-couple device is shown in Figure 1. A rather even distribution of micrometer-sized water droplets within the palm oil layer at $50 \times$ magnification was observed. The mean diameter of the water droplets was $0.229 \mu \mathrm{m}$. Mechanical stirring using a homogenizer was employed to mix the added water of $0.05 \mathrm{wt} . \%$ with the palm oil without adding any surfactant before observing and capturing the results using optical microscope 
equipment. Micro-explosion might occur after the $\mu \mathrm{m}$-sized water droplets absorbed sufficient surrounding heat to explode outwards through enveloping oil layer [26], leading to much increase of contacting surface among the reactants and in turn a larger extent of chemical reaction. In addition, the even distribution of $\mu \mathrm{m}$-sized water droplets in palm oil might increase the homogeneous mixing extent with hydrophilic methanol, leading to enhancement of alkali-catalyzed reaction and formation of fatty acid methyl esters.

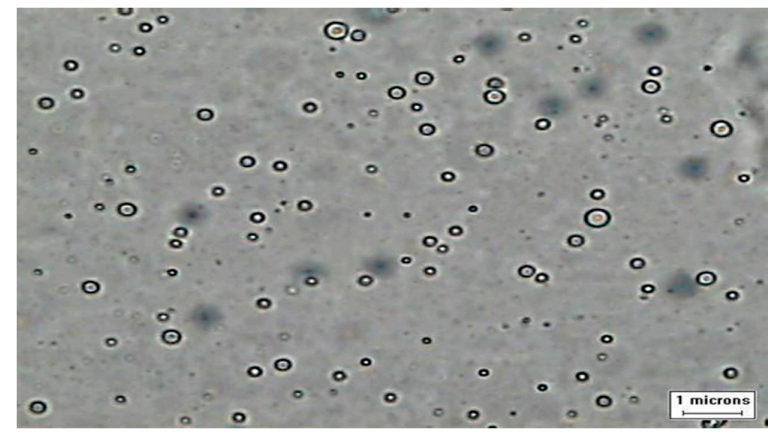

Figure 1. Photograph of physical structure of water droplets distributed within palm oil layer when $0.05 \mathrm{wt} . \%$ water was added.

Fatty acid methyl esters (FAME) were produced from the transesterification of triglyceride-rich vegetable oil or animal fats with short-chain alcohol particularly methanol. The FAME content is available to determine the extent of transesterification. Higher FAME amount indicates higher purity of the biodiesel product [27]. On the contrary, inferior fuel properties exist for a biodiesel with lower FAME content. The Gas chromatograph (GC) method was used to analyze the fatty acid compositions of the biodiesel produced from palm oil with seven different water contents added. The results of the fatty acid compositions, analyzed by GC equipment, are shown in Table 2. Biodiesel is excellent alternative fuel to petro-diesel due to their similar carbon-chain structure and fuel characteristics. The fatty acid compositions of biodiesel made from vegetable oil or animal fat are mostly in the similar range between $\mathrm{C} 14$ and $\mathrm{C} 18$ as those carbon-chains of petro-diesel. This can be justified that the total contents of FAME in the range between C14 and C18 for those seven biodiesel samples are only from 81.1 wt.\% to 82.1 wt.\%. In addition, the FAME contents of carbon chains longer than C16 of those seven biodiesel samples are at least $80.9 \mathrm{wt}$.\% in Table 2. The FAME produced from palm oil added with $0.05 \mathrm{wt} . \%$ water content was observed to have the highest saturated fatty acids, which amounted to 46.3 wt.\%. Carbon chains of fatty acids ranging from C14 to C24 are frequently identified in biodiesel samples made from various feedstocks. The fatty acid compositions in Table 2 are similar to those of biodiesel structures in previous studies [28,29]. Hence, the biodiesels in this study were successfully produced. The total contents of the palmitic acid (C16:0), stearic acid (C18:0), and oleic acid (C18:1) of those biodiesels accounted for more than $70 \mathrm{wt} . \%$ in Table 2 , which agrees well with the results of Pinzi et al. [30].

Table 2. Comparison of fatty acid compositions of the biodiesel produced from palm oil added with various water content through transesterification.

\begin{tabular}{cccccccc}
\hline \multirow{2}{*}{ Types of Fatty Acids } & \multicolumn{7}{c}{ Added Water Contents (wt.\%) } \\
\cline { 2 - 8 } & $\mathbf{0 . 0 2}$ & $\mathbf{0 . 0 3}$ & $\mathbf{0 . 0 5}$ & $\mathbf{0 . 0 7}$ & $\mathbf{0 . 0 9}$ & $\mathbf{0 . 1 1}$ & $\mathbf{0 . 1 2}$ \\
\hline C14:0 & 0.8 & 0.6 & 0.8 & 0.6 & 0.6 & 0.6 & 0.8 \\
C16:0 & 33.3 & 31.1 & 34.2 & 27.6 & 27.3 & 28.3 & 34.1 \\
C18:0 & & 14.1 & 11.2 & 14.6 & 15.5 & 48.9 & 43.2 \\
C18:1 & 43.4 & 32.4 & 31.7 & 35.4 & 34.4 & & \\
\hline
\end{tabular}


Table 2. Cont.

\begin{tabular}{cccccccc}
\hline \multirow{2}{*}{ Types of Fatty Acids } & \multicolumn{7}{c}{ Added Water Contents (wt. \%) } \\
\cline { 2 - 8 } & $\mathbf{0 . 0 2}$ & $\mathbf{0 . 0 3}$ & $\mathbf{0 . 0 5}$ & $\mathbf{0 . 0 7}$ & $\mathbf{0 . 0 9}$ & $\mathbf{0 . 1 1}$ & $\mathbf{0 . 1 2}$ \\
\hline C18:2 & 3.6 & 3.9 & 3.8 & 3.4 & 3.4 & 3.3 & 3.2 \\
C18:3 & 0.4 & & & 0.1 & 0.1 & & \\
C24:0 & 0.1 & 0.1 & 0.1 & 0.1 & 0.1 & 0.1 & 0.1 \\
C24:1 & 0.3 & 0.3 & 0.2 & 0.3 & 0.3 & 0.3 & 0.3 \\
Saturated fatty acids & - & 45.9 & 46.3 & 42.9 & 43.5 & - & - \\
Longer carbon-chain & 81.1 & 81.9 & 81.2 & 81.5 & 81.1 & 80.9 & 80.9 \\
fatty acids than C16 & 93.5 & 95 & 97.3 & 95.3 & 94.1 & 93.3 & 93.7 \\
Total FAME & & & & & & &
\end{tabular}

The variations in the total fatty acid compositions with water contents added to the palm oil are shown in Figure 2. The highest content of fatty acid methyl esters, which amounted to $97.3 \mathrm{wt} . \%$, was produced from palm oil with $0.05 \mathrm{wt} . \%$ water added. This is probably owing to the enhancement of the dissociation of $\mathrm{OH}^{-}$radicals from the water to conjugate with the long carbon-chain fatty acids. Although Wu et al. [31] suggested that a water content that is as low as possible in raw oil is required to result in a more complete transesterification reaction, insufficient or excessive amounts of $\mathrm{OH}^{-}$radicals dissociated from the water might be ineffective to move forward the transesterification reaction. Hence, adequate water content would facilitate the conversion reaction, and this postulate agrees well with Nguyen et al. [32]. Less or larger than $0.05 \mathrm{wt} . \%$ water added to the palm oil caused less extent of transesterification and thus lower production of total fatty acid methyl esters (FAME) in Figure 2. Hence, the lower FAME formation appeared when the biodiesel produced from palm oil added with $0.02 \mathrm{wt.} \%$ or $0.11 \mathrm{wt} . \%$ water contents. Sun et al. [33] found that water content was negative to algae dissolution and [Bmim] $\left[\mathrm{HSO}_{4}\right]$ catalyzed in-situ transesterification. The biodiesel production from wet algae was thus reduced. Arumugam and Ponnusami [34] observed that the highest conversion rate of triglycerides $(92.5 \%)$ was produced from waste sardine oil at a water content of $10 \mathrm{vol} . \%$ for transesterification reaction catalyzed by enzymes. Excess water in reactants favors hydrolysis and thus decreases biodiesel production.

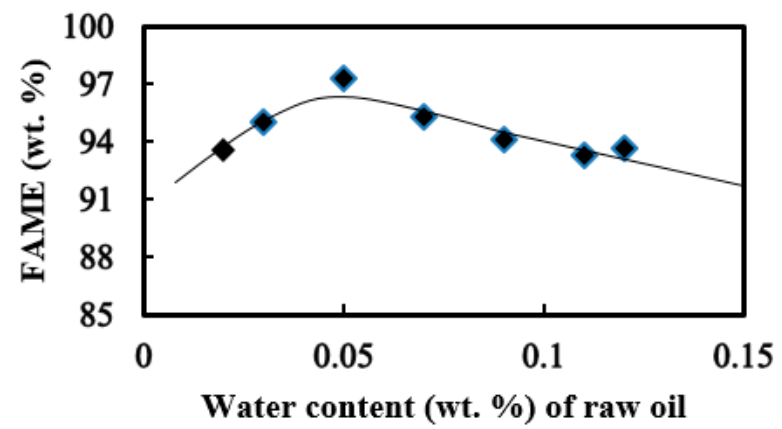

Figure 2. Effects of added water content in palm oil on the fatty acid methyl esters.

Table 2 reveals the analytic results of fatty acid methyl esters from the biodiesel produced from palm oil with various water contents added. The biodiesel produced from palm oil with $0.05 \mathrm{wt} . \%$ water added was primarily composed of palmitic acid (C16:0), oleic acid (C18:1), and stearic acid (C18:0), which accounted for $34.2 \mathrm{wt} . \%, 31.7 \mathrm{wt} . \%$, and $11.2 \mathrm{wt} . \%$, respectively. This implies that the biodiesel is relatively oxidatively stable, and thus, fuel properties are not prone to deterioration. In contrast, the biodiesels produced from palm oil added with $0.02 \mathrm{wt} . \%$ and $0.12 \mathrm{wt} . \%$ water were shown to have much less formation of total fatty acid methyl esters. The content of fatty acids from $\mathrm{C} 16$ to $\mathrm{C} 18$ amounted to $80.7 \mathrm{wt} . \%$ and $80.5 \mathrm{wt} . \%$ for the biodiesel made from palm oil added with $0.02 \mathrm{wt} . \%$ and $0.12 \mathrm{wt} . \%$ water, respectively. This implied that although the biodiesel made from palm oil added with water contents from $0.02 \mathrm{wt} . \%$ to $0.12 \mathrm{wt} . \%$ resulted in various extents of transesterification and 
different amounts of fatty acid methyl esters, all the biodiesel produced were composed of almost carbon-chained compounds from $\mathrm{C} 16$ to $\mathrm{C} 18$. Hence, the biodiesel products are adequate alternative fuel to petro-diesel due to similar carbon-chain chemical structure. Moreover, palm oil is a competitive and abundant feedstock oil source for biodiesel production.

Free fatty acids might be produced through the hydrolysis of fatty acids with water [35]. Excessive water content in reactant mixture of esterification reaction might cause frequent attack of lipids by water. Fatty acids of longer carbon chain lengths would be hydrolyzed, resulting in the formation of free fatty acids and shorter carbon-chain fatty acids [36]. The chemical composition of the biofuel is changed accordingly, resulting in worsened fuel properties. The significant phenomena arising are the occurrence of odor, viscosity increase, and color change, which is the so-called rancidity of the lipid [37].

\subsection{Heating Value}

The heating value is defined as the amount of heat released from the complete burning of fuel. Fuel with a higher heating value requires only lower fuel consumption to attain the same power output. The heating value of biodiesel is lower than petro-diesel by around $10 \%$ [38]. The heating values of biodiesels made from palm oil were in the range of $39.5 \mathrm{MJ} / \mathrm{kg}$ to $40.9 \mathrm{MJ} / \mathrm{kg}$ and were shown to increase with the increase in added water content to the palm oil, as seen in Figure 3. Biodiesel produced from palm oil with $0.12 \mathrm{wt} . \%$ water added was found to have the highest heating value, while that with $0.02 \mathrm{wt} . \%$ water added had the lowest heating value among those biodiesels, as shown in Figure 3. Shi et al. [10] found that water content that was too low might cause a low extent of hydrolysis of lipid towards reformation of fatty acid methyl esters during transesterification, resulting in a low conversion rate from raw oil and thus, a reduced heating value. In contrast, high water content might render continuous hydrolysis of lipid to form $\mathrm{H}^{+}$and $\mathrm{OH}^{-}$radicals and in turn biodiesel, as observed by $\mathrm{He}$ et al. [39]. Caetano et al. [40] inferred that water presence might lead to the enhancement of catalytic activity of lipase because the alcohol removed the hydration layer of the enzyme. Adequate water existence thus facilitates both transesterification and hydrolysis. Therefore, higher water content in the raw palm oil appeared to have a higher heating value in the biodiesel product.

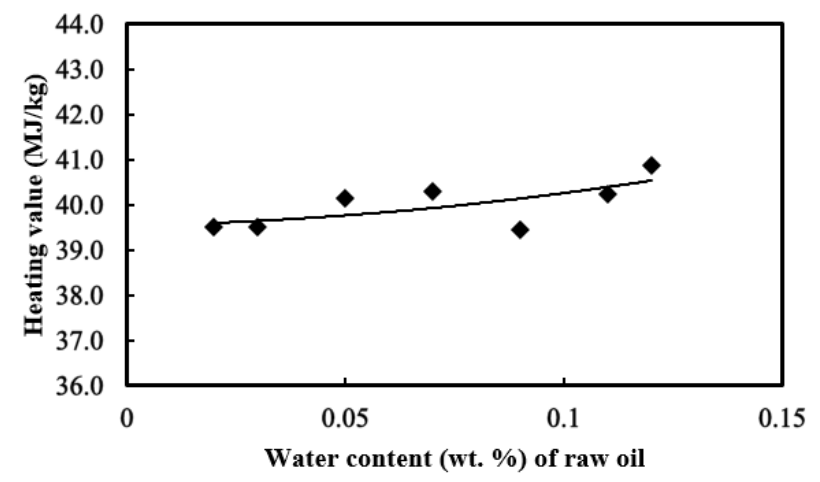

Figure 3. Effects of added water content in palm oil on the heating value of the biodiesel product.

Elsanusi et al. [41] investigated the effects of water concentrations in biodiesel emulsions on fuel characteristics and engine performance. They found that the brake thermal efficiency (BTE) increased with the increase of water content in the biodiesel emulsions. This implies that a larger amount of heat was released from burning the biodiesel emulsion with larger water content to result in higher BTE.

\subsection{Specific Gravity}

Specific gravity is defined as the ratio of density of some liquid to that of water at $4{ }^{\circ} \mathrm{C}$. The specific gravity of biodiesel is in the range of 0.86 to 0.9 based on the EN 14,214 standard. The highest and lowest specific gravities were observed for the biodiesel made from palm oil with 0.09 and $0.02 \mathrm{wt} . \%$ water added, as shown in Figure 4. The curve trend of specific gravity shown in Figure 4 almost 
totally agrees with that of the fatty acid methyl esters of the biodiesel product shown in Figure 2. Hence, a lower specific gravity corresponds to a lower total FAME content of the biodiesel. In addition, the type of fatty acid compositions influences the specific gravity of the biodiesel. For example, a larger content of longer carbon-chain fatty acids appeared to create a larger specific gravity of the biodiesel, as found by Hajilar and Shafei [42].

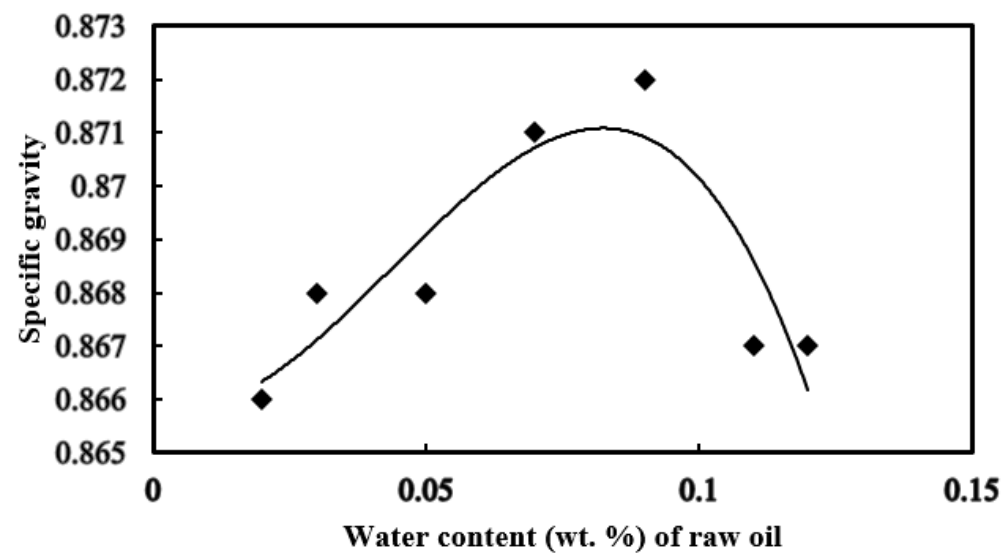

Figure 4. Effects of added water content in palm oil on the specific gravity of the biodiesel product.

Ramírez-Verduzco et al. [43] presented characterization of two biodiesel samples through their FAME profiles and derived empirical equations to correlate biodiesel properties with their fatty acid structures. They found that the specific gravity of biodiesel increased as molecular weight decreased and degree of unsaturation increased. The larger specific gravity of the biodiesel made from palm oil added with 0.09 wt. $\%$ might thus be ascribed to its larger content of unsaturated fatty acids, as shown in Table 2. Refaat [44] and Folayan et al. [45] also confirmed that specific gravity of biodiesel increases with the increase of unsaturated fatty acids and the decrease of chain length.

\subsection{Flash Point and Ignition Point}

The flash point is one major safety indicator during storage and transportation of liquid fuel. The temperature at which liquid fuel is heated to form and accumulate fuel vapor to a certain concentration, where an instantaneous spark is flashed after a flame crosses over the fuel vapor, is defined as the flash point. The temperature at which the fuel vapor is formed to cause the spark and further continuous burning is denoted as the ignition point of liquid fuel. The flash points of biodiesel were found to range from 160 to $176{ }^{\circ} \mathrm{C}$ and peaked corresponding to the $0.05 \mathrm{wt}$. $\%$ water content added to the palm oil, as shown in Figure 5. The curve trend of the flash point shown in Figure 5 conformed to that of FAME profile in Figure 2. The highest FAME content in biodiesel rendered the highest flash point when $0.05 \mathrm{wt}$. \% water was added to raw palm oil. The peak flash point could also be observed from Table 2, where the total carbon-chain fatty acids for the biodiesel produced from palm oil with $0.05 \mathrm{wt}$ \% water content added reached the highest $97.3 \mathrm{wt} . \%$ among all the cases of added water contents. Marlina et al. [46] also found that biodiesel composed of a greater content of longer carbon-chain fatty acids tended to have a higher flash point. Too high or low added water to raw oil caused a slower nucleophilic substitution reaction, as proposed by Paula et al. [47]. A lower conversion rate thus occurred, resulting in a lower FAME and in turn a lower flash point in those cases. The flash point was decreased with the increase of the content of unsaturated fatty acid methyl esters in Figure 5-a result that agreed with that of Ayoola [48]. Su et al. [49] proposed a correlation equation of flash point with chain length and unsaturation of biodiesel. Rao et al. [50] also derived a correlation equation to relate flash point of biodiesel linearly with its specific gravity. Hence, similar curve trends between those of specific gravity and flash point could be observed in Figures 4 and 5. Flash point was also observed to influence higher heating values of biodiesel [51]. 


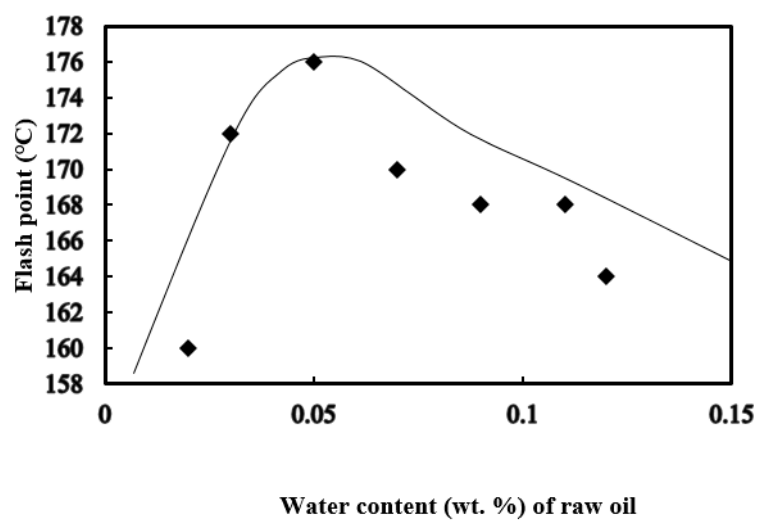

Figure 5. Effects of added water content in palm oil on the flash point of the biodiesel product.

The highest ignition point of biodiesel was found to be made from palm oil with $0.05 \mathrm{wt} . \%$ water content added, as shown in Figure 6. This can probably be ascribed to the highest FAME formation among the biodiesels from palm oil with various water contents added, shown in Figure 2 . In comparison with Figure 2, the curve trend of the ignition points of the biodiesel with respect to the added water content in Figure 6 was observed to agree with that of FAME contents in the biodiesel products. This implies that higher FAME content in the biodiesel product increased the ignition point. In addition, the higher specific gravity of the biodiesel was shown to have a higher ignition point in comparison to Figures 4 and 6; this inference agrees well with the findings of Kumar and Bansal [52] and Rao et al. [50]. The increase of ignition point might also be ascribed to the increase of saturated fatty acid methyl esters, as observed by Ayoola [48]. Bukkarapu et al. [53] found that the increase of kinematic viscosity caused the increase of ignition point of the biodiesel.

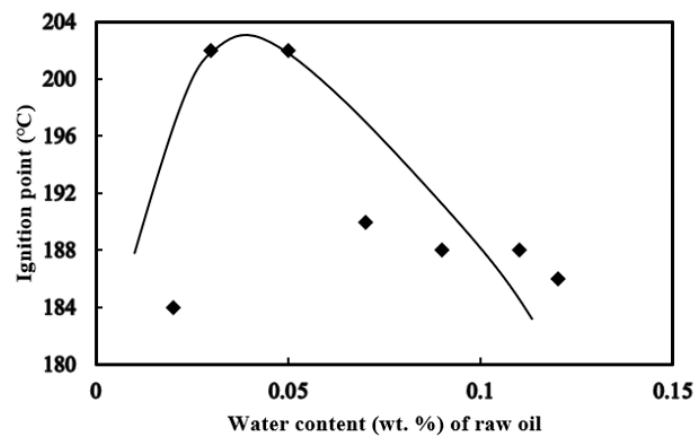

Figure 6. Effects of added water content in palm oil on the ignition point of the biodiesel product.

\subsection{Distillation Temperature and Cetane Index}

Distillation temperature is one of the significant indicators of volatility and combustion characteristics of liquid fuel. The tendency of forming smoke and soot can be indicated by distillation temperature as well. In contrast to the distillation temperatures of petro-diesel, biodiesel has much narrower range of boiling points due to mostly alkyl esters in biodiesel [54]. A distillation temperature curve based on ASTM D86 is prepared to reveal the range of boiling points of various compounds in liquid fuel. The curve of the distillation temperatures can be used to determine the distribution from light to heavy compounds. The temperature at which a liquid drop is vaporized, condensed, and collected is referred to as $\mathrm{T}_{\mathrm{IBP}}$. Similarly, $\mathrm{T}_{50}$ is the temperature for a $50 \mathrm{vol} \%$ liquid fuel, and $\mathrm{T}_{\mathrm{EP}}$ is the highest temperature corresponding to the final liquid drop that is vaporized, condensed, and collected.

The ASTM D86 distillation temperature curve for biodiesel made from palm oil with various water contents added, ranging from $0.03 \mathrm{wt} . \%$ to $0.12 \mathrm{wt} . \%$, is shown in Figure 7 . Biodiesel made from palm oil with $0.05 \mathrm{wt} . \%$ water added was found to have the highest distillation temperature, while that 
with $0.12 \mathrm{wt} . \%$ water added had the lowest distillation temperatures among those three biodiesels. For example, the $\mathrm{T}_{\mathrm{EP}}$ of the biodiesel made from palm oil added with $0.05 \mathrm{wt} . \%$ and $0.12 \mathrm{wt} . \%$ water contents were 354 and $342{ }^{\circ} \mathrm{C}$, respectively. This is ascribed to the fact that the addition of $0.05 \mathrm{wt} . \%$ water content caused the highest formation of fatty acid methyl esters (FAME), while that of $0.12 \mathrm{wt} . \%$ water formed the lowest FAME, as shown in Figure 2. In addition, Yao et al. [55] considered that $\mathrm{T}_{90}$ is an indicator for the content of heavier compounds in liquid fuel. A higher $\mathrm{T}_{90}$ implies a larger amount of heavier compounds and greater viscosity of a liquid fuel, which might result in deteriorated atomization, slower vaporization, and in turn, incomplete burning. The biodiesel made from palm oil with $0.05 \mathrm{wt} . \%$ water added was shown to have the highest $\mathrm{T}_{90}$, which thus implies production of a higher extent of pollutants from burning such biodiesel. Distillation temperature influences the combustion and emission characteristics of biodiesel. Lower distillation temperature results in higher volatility and enhances homogeneity of reactant mixture [56].

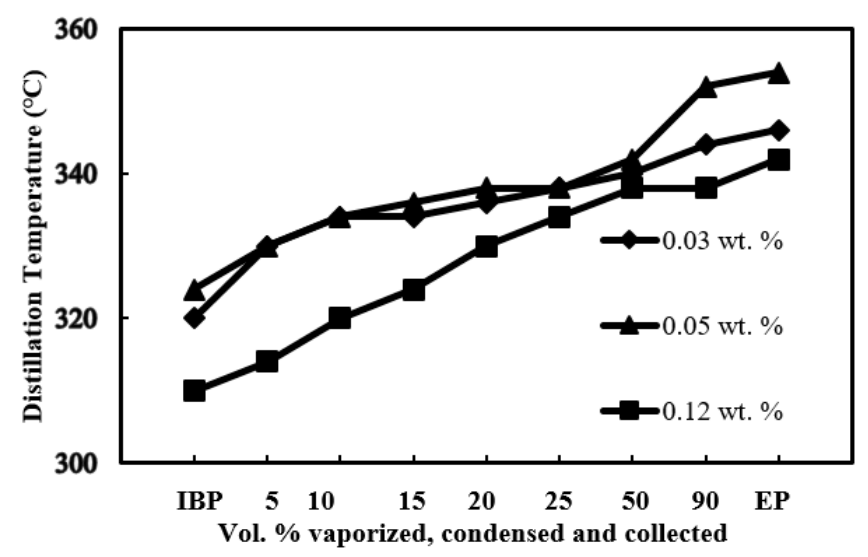

Figure 7. Effects of added water content in palm oil on the distillation temperature curve of the biodiesel product.

The cetane number $(\mathrm{CN})$ is used to indicate the compression-ignition quality of liquid fuel in a diesel engine. Fuel bearing a higher cetane number would shorten the period of ignition delay in a diesel engine and thus reduce the burning time and residence period of the peak flame within the engine cylinder, resulting in a lower occurrence of engine knocking and NOx formation. The cetane index, which is an alternative to the cetane number, is obtained by calculations using the data from $\mathrm{T}_{50}$ and API gravity based on Equation (3). The lowest cetane index is found for biodiesel made from palm oil with 0.09 wt.\% water added, shown in Figure 8. This is probably due to its larger $T_{50}$ and the specific gravity of the biodiesel, as shown in Figure 4. A higher cetane index existed when water content that was either lower or higher than $0.09 \mathrm{wt} . \%$ was added to palm oil for manufacturing the biodiesel. Cetane number of biodiesel was determined by its fatty acid composition, number of double bonds, degree of unsaturation, chain length, and molecular weight [57]. A few correlation equations which relate cetane number with those physicochemical properties of biodiesel have been proposed for $\mathrm{CN}$ prediction [58,59]. In addition, Mishra et al. [60] and Moser [61] found that the cetane number of the biodiesel increased with the increased amount of long carbon-chain fatty acids or saturated fatty acids. It was found that the increase of number of double bonds leads to the decrease of cetane number of biodiesel [62]. Higher or lower water content than $0.09 \mathrm{wt} . \%$ might cause an increase in saturated fatty acids and heating value in turn. Hence, those two curve trends between the cetane index and heating value agree well with each other in comparison with Figures 3 and 8. 


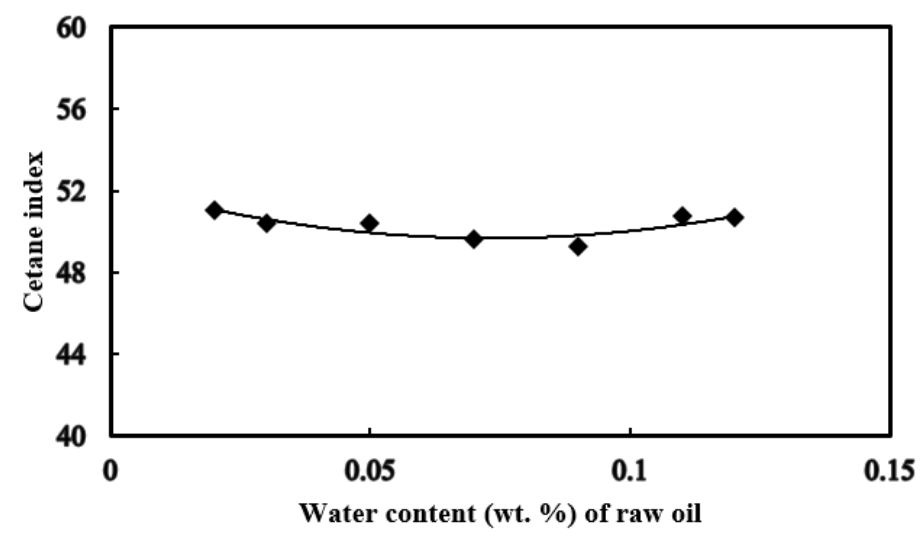

Figure 8. Effects of added water content in palm oil on the cetane index of the biodiesel product.

\section{Conclusions}

Various water contents were added to palm oil to undergo strong alkaline-catalyst transesterification for biodiesel production. The burning characteristics of those fatty acid methyl esters, such as flash point and heating value, were analyzed. Major experimental results are summarized below.

A rather even distribution of water droplets with the mean diameter of $0.229 \mu \mathrm{m}$ within the palm oil layer was produced when $0.05 \mathrm{wt} . \%$ water was added to the raw palm oil and stirred using a mechanical stirrer. The fatty acid methyl esters produced from the palm oil with the water added ranging from $0.02 \mathrm{wt} . \%$ to $0.12 \mathrm{wt} . \%$ were composed of over $70 \mathrm{wt} . \%$ of palmitic acid (C16:0), stearic acid (C18:0), and oleic acid (C18:1). The biodiesel produced from palm oil with $0.05 \mathrm{wt} . \%$ water added through strong alkaline-catalyst transesterification were found to form the highest total fatty acid methyl esters (FAME) and saturated fatty acids, which amounted to $97.3 \mathrm{wt} . \%$ and $46.3 \mathrm{wt} . \%$, respectively among those seven biodiesel samples. Moreover, the fatty acid methyl esters produced from palm oil with $0.05 \mathrm{wt} . \%$ water added appeared to have the highest flash point, ignition point, and distillation temperature and thus, the highest safety level during storage and transportation of the biodiesel. The total carbon-chain fatty acids longer than C16 reached as high as $81.2 \mathrm{wt} . \%$ in such biodiesel. The raw palm oil with $0.05 \mathrm{wt}$.\% water content was found to produce a biodiesel with superior fatty acid composition and fuel characteristics.

In contrast, the biodiesel produced from palm oil with $0.02 \mathrm{wt} . \%$ water added was found to have the lowest heating value and specific gravity. The lowest distillation temperature and formation of fatty acid methyl esters were found to be in the biodiesel made from palm oil with $0.12 \mathrm{wt} . \%$ water added. In addition, biodiesel made from palm oil with $0.09 \mathrm{wt} . \%$ water added was observed to have the highest specific gravity along with the lowest cetane index. Hence, added water content higher or lower than $0.05 \mathrm{wt} . \%$, such as $0.02 \mathrm{wt} . \%$ and $0.12 \mathrm{wt} . \%$, caused poorer fatty acids compositions and deteriorated fuel properties.

Author Contributions: Conceptualization, principal investigation, experimental design, funding acquisition, writing and editing, and supervision, C.-Y.L.; carrying out experiment and data acquisition, L.M. All authors have read and agreed to the published version of the manuscript.

Funding: This research was funded by the Ministry of Science and Technology, Taiwan, ROC under grant number: MOST 107-2221-E-019-056-MY2 and MOST 105-2221-E-019-066 and the APC was funded by National Taiwan Ocean University, Taiwan, ROC.

Conflicts of Interest: The authors declare no conflict of interest.

\section{References}

1. Østerstrøm, F.F.; Anderson, J.E.; Mueller, S.A.; Collings, T.; Ball, J.C.; Wallington, T.J. Oxidation stability of rapeseed biodiesel/petroleum diesel blends. Energy Fuels 2016, 30, 344-351. [CrossRef]

2. Othman, M.F.; Adam, A.; Najafi, G.; Mamat, R. Green fuel as alternative fuel for diesel engine: A review. Renew. Sustain. Energy Rev. 2017, 80, 694-709. [CrossRef] 
3. Kandasamy, S.; Samudrala, S.P.; Bhattacharya, S. The route towards sustainable production of ethylene glycol from a renewable resource, biodiesel waste: A review. Cat. Sci. Tec. 2019, 9, 567-577. [CrossRef]

4. Ahmmad, M.S.; Haji Hassan, M.B.; Kalam, M.A. Comparative corrosion characteristics of automotive materials in Jatropha biodiesel. Int. J. Green Energy 2018, 15, 393-399. [CrossRef]

5. Santos, D.; da Rocha, E.C.; Santos, R.L.; Cancelas, A.J.; Franceschi, E.; Santos, A.F.; Fortuny, M.; Dariva, C. Demulsification of water-in-crude oil emulsions using single mode and multimode microwave irradiation. Sep. Purif. Technol. 2017, 189, 347-356. [CrossRef]

6. di Bitonto, L.; Pastore, C. Metal hydrated-salts as efficient and reusable catalysts for pre-treating waste cooking oils and animal fats for an effective production of biodiesel. Renew. Energy 2019, 143, 1193-1200. [CrossRef]

7. Hakimi, M.I.; Goembira, F.; Ilham, Z. Engine-compatible biodiesel from Leucaena leucocephala seed oil. J. Soc. Automot. Eng. Malays. 2017, 1, 86-93.

8. Yaşar, F. Comparision of fuel properties of biodiesel fuels produced from different oils to determine the most suitable feedstock type. Fuel 2020, 264, 116817. [CrossRef]

9. Chen, J.; Li, J.; Dong, W.; Zhang, X.; Tyagi, R.D.; Drogui, P.; Surampalli, R.Y. The potential of microalgae in biodiesel production. Renew. Sustain. Energy Rev. 2018, 90, 336-346. [CrossRef]

10. Shi, W.J.; Liu, H.Q.; Feng, S.B.; Zheng, E.L. Study on preparation of biodiesel with low acid value rapeseed oil. Renew. Energy Resour. 2009, 27, 37-39.

11. Jia, W.; Xu, G.; Liu, X.; Zhou, F.; Ma, H.; Zhang, Y.; Fu, Y. Direct Selective Hydrogenation of Fatty Acids and Jatropha Oil to Fatty Alcohols over Cobalt-Based Catalysts in Water. Energy Fuels 2018, 32, 8438-8446. [CrossRef]

12. Zhang, Z.; Jiaqiang, E.; Chen, J.; Zhu, H.; Zhao, X.; Han, D.; Yin, Z. Effects of low-level water addition on spray, combustion and emission characteristics of a medium speed diesel engine fueled with biodiesel fuel. Fuel 2019, 239, 245-262. [CrossRef]

13. Rao, M.S.; Anand, R.B. Performance and emission characteristics improvement studies on a biodiesel fuelled DICI engine using water and $\mathrm{AlO}(\mathrm{OH})$ nanoparticles. Appl. Therm. Eng. 2016, 98, 636-645.

14. Sudalaimuthu, G.; Rathinam, S.; Munuswamy, D.B.; Thirugnanasambandam, A.; Devarajan, Y. Testing and evaluation of performance and emissions characteristics of water-biodiesel aspirated research engine. J. Test. Eval. 2020, 48, 20180306. [CrossRef]

15. Zakaria, H.; Khalid, A.; Sies, M.F.; Mustaffa, N.; Manshoor, B. Effect of storage temperature and storage duration on biodiesel properties and characteristics. Appl. Mech. Mater. 2014, 465, 316-321. [CrossRef]

16. Lawan, I.; Zhou, W.; Idris, A.L.; Jiang, Y.; Zhang, M.; Wang, L.; Yuan, Z. Synthesis, properties and effects of a multi-functional biodiesel fuel additive. Fuel Process. Technol. 2020, 198, 106228. [CrossRef]

17. Delfino, J.R.; Pereira, T.C.; Viegas, H.D.C.; Marques, E.P.; Ferreira, A.A.P.; Zhang, L.; Marques, A.L.B. A simple and fast method to determine water content in biodiesel by electrochemical impedance spectroscopy. Talanta 2018, 179, 753-759. [CrossRef]

18. Kusdiana, D.; Saka, S. Effects of water on biodiesel fuel production by supercritical methanol treatment. Bioresour. Technol. 2004, 91, 289-295. [CrossRef]

19. Tan, K.T.; Lee, K.T.; Mohamed, A.R. Effects of free fatty acids, water content and co-solvent on biodiesel production by supercritical methanol reaction. J. Supercrit. Fluids 2010, 53, 88-91. [CrossRef]

20. Srimhan, P.; Kongnum, K.; Taweerodjanakarn, S.; Hongpattarakere, T. Selection of lipase producing yeasts for methanol-tolerant biocatalyst as whole cell application for palm-oil transesterification. Enzyme Microb. Technol. 2011, 48, 293-298. [CrossRef]

21. Yan, S.; Salley, S.O.; Ng, K.Y.S. Simultaneous transesterification and esterification of unrefined or waste oils over ZnO-La2O3 catalysts. Appl. Catal. A. 2009, 353, 203-212. [CrossRef]

22. Shimadzu Corporation. GC-2014 Gas Chromatograph Instruction Manual; Shimadzu Corporation: Kyoto, Japan, 2014.

23. International Organization for Standardization. Determination of Flash Point-Rapid Equilibrium Closed Cup Method; American National Standard Institute: Washington, DC, USA, 2015; ISO 3679:2015.

24. Kalargaris, I.; Tian, G.; Gu, S. Experimental evaluation of a diesel engine fuelled by pyrolysis oils produced from low-density polyethylene and ethylene-vinyl acetate plastics. Fuel Process. Technol. 2017, 161, 125-131. [CrossRef] 
25. Holman, J.P. Analysis of experimental data. In Experimental Methods for Engineers, 8th ed.; McGraw Hill Inc.: Singapore, 2012; pp. 60-77.

26. Moussa, O.; Tarlet, D.; Massoli, P.; Bellettre, J. Parametric study of the micro-explosion occurrence of W/O emulsions. Int. J. Therm. Sci. 2018, 133, 90-97. [CrossRef]

27. Pangestu, T.; Kurniawan, Y.; Soetaredjo, F.E.; Santoso, S.P.; Irawaty, W.; Yuliana, M.; Ismadji, S. The synthesis of biodiesel using copper based metal-organic framework as a catalyst. J. Environ. Chem. Eng. 2019, 7, 103277. [CrossRef]

28. Hoekman, S.K.; Broch, A.; Robbins, C.; Ceniceros, E.; Natarajan, M. Review of biodiesel composition, properties, and specifications. Renew. Sustain. Energy Rev. 2012, 16, 143-169. [CrossRef]

29. Singh, D.; Sharma, D.; Soni, S.L.; Sharma, S.; Kumari, D. Chemical compositions, properties, and standards for different generation biodiesels: A review. Fuel 2019, 253, 60-71. [CrossRef]

30. Pinzi, S.; Leiva, D.; Arzamendi, G.; Gandia, L.M.; Dorado, M.P. Multiple response optimization of vegetable oils fatty acid composition to improve biodiesel physical properties. Bioresour. Technol. 2011, 102, 7280-7288. [CrossRef]

31. Wu, L.; Wei, T.Y.; Tong, Z.F.; Zou, Y.; Lin, Z.J.; Sun, J.H. Bentonite-enhanced biodiesel production by $\mathrm{NaOH}$-catalyzed transesterification of soybean oil with methanol. Fuel Process. Technol. 2016, 144, 334-340. [CrossRef]

32. Nguyen, H.C.; Nguyen, M.L.; Wang, F.M.; Juan, H.Y.; Su, C.H. Biodiesel production by direct transesterification of wet spent coffee grounds using switchable solvent as a catalyst and solvent. Bioresour. Technol. 2020, 296, 122334. [CrossRef]

33. Sun, Y.; Xu, C.; Igou, T.; Liu, P.; Hu, Z.; Van Ginkel, S.W.; Chen, Y. Effect of water content on [Bmim][HSO4] assisted in-situ transesterification of wet Nannochloropsis oceanica. Appl. Energy 2018, 226, 461-468. [CrossRef]

34. Arumugam, A.; Ponnusami, V. Production of biodiesel by enzymatic transesterification of waste sardine oil and evaluation of its engine performance. Heliyon 2017, 3, e00486. [CrossRef]

35. Oliverira, E.D.C.; Silva, P.R.D.; Ramos, A.P.; Aranda, D.A.G.; Freire, D.M.G. Study of soybean oil hydrolysis catalyzed by Thermomyces Ianuginosus lipase and its application to biodiesel production via hydroesterification. Enzyme Res. 2011, 2011, 1-8. [CrossRef] [PubMed]

36. Edeh, I.; Overton, T.; Bowra, S. Optimization of subcritical water-mediated lipid extraction from activated sludge for biodiesel production. Biofuels 2019, 1-7. [CrossRef]

37. Nejad, A.S.; Zahedi, A.R. Optimization of biodiesel production as a clean fuel for thermal power plants using renewable energy source. Renew. Energy 2018, 119, 365-374. [CrossRef]

38. Yamin, J.A.; Sheet, E.A.E.; Hdaib, I. Exergy analysis of biodiesel fueled direct injection CI engines. Energy Sources Part A 2018, 40, 1351-1358. [CrossRef]

39. He, Y.; Wu, T.; Wang, X.; Chen, B.; Chen, F. Cost-effective biodiesel production from wet microalgal biomass by a novel two-step enzymatic process. Bioresour. Technol. 2018, 268, 583-591. [CrossRef]

40. Caetano, N.S.; Caldeira, D.; Martins, A.A.; Mata, T.M. Valorisation of spent coffee grounds: Production of biodiesel via enzymatic catalysis with ethanol and a co-solvent. Waste Biomass Valori. 2017, 8, 1981-1994. [CrossRef]

41. Elsanusi, O.A.; Roy, M.M.; Sidhu, M.S. Experimental investigation on a diesel engine fueled by diesel-biodiesel blends and their emulsions at various engine operating conditions. Appl. Energy 2017, 203, 582-593. [CrossRef]

42. Hajilar, S.; Shafei, B. Thermal transport properties at interface of fatty acid esters enhanced with carbon-based nanoadditives. Int. J. Heat Mass Tran. 2019, 145, 118762. [CrossRef]

43. Ramírez-Verduzco, L.F.; Rodríguez-Rodríguez, J.E.; del Rayo Jaramillo-Jacob, A. Predicting cetane number, kinematic viscosity, density and higher heating value of biodiesel from its fatty acid methyl ester composition. Fuel 2012, 91, 102-111. [CrossRef]

44. Refaat, A.A. Correlation between the chemical structure of biodiesel and its physical properties. Int. J. Environ. Sci. Technol. 2009, 6, 677-694.

45. Folayan, A.J.; Anawe, P.A.L.; Aladejare, A.E.; Ayeni, A.O. Experimental investigation of the effect of fatty acids configuration, chain length, branching and degree of unsaturation on biodiesel fuel properties obtained from lauric oils, high-oleic and high-linoleic vegetable oil biomass. Energ. Rep. 2019, 5, 793-806. [CrossRef]

46. Marlina, E.; Wijayanti, W.; Yuliati, L.; Wardana, I.N.G. The role of pole and molecular geometry of fatty acids in vegetable oils droplet on ignition and boiling characteristics. Renew. Energy 2020, 145, 596-603. [CrossRef] 
47. Paula, A.J.; Stéfani, D.; Filho, A.G.S.; Kim, Y.A.; Endo, M.; Alves, O.L. Surface chemistry in the process of coating mesoporous $\mathrm{SiO}_{2}$ onto carbon nanotubes driven by the formation of Si-O-C Bonds. Chem.-Eur. J. 2011, 17, 3228-3237. [CrossRef] [PubMed]

48. Ayoola, A.A.; Anawe, P.A.L.; Ojewumi, M.E.; Amaraibi, R.J. Comparison of the properties of palm oil and palm kerneloil biodiesel in relation to the degree of unsaturation of their oil feedstocks. Int. J. App. Nat. Sci. 2016, 5, 1-8.

49. Su, Y.C.; Liu, Y.A.; Diaz Tovar, C.A.; Gani, R. Selection of prediction methods for thermophysical properties for process modeling and product design of biodiesel manufacturing. Ind. Eng. Chem. Res. 2011, 50, 6809. [CrossRef]

50. Rao, G.L.N.; Ramadhas, A.S.; Nallusamy, N.; Sakthivel, P. Relationships among the physical properties of biodiesel and engine fuel system design requirement. Int. J. Energ. Environ. 2010, 1, 919-926.

51. Sivaramakrishnan, K.; Ravikumar, P. Determination of cetane number of biodiesel and its influence on physical properties. ARPN J. Eng. Appl. Sci. 2012, 7, 205-211.

52. Kumar, J.; Bansal, A. Application of artificial neural network to predict properties of diesel—biodiesel blends. Kathman Univ. J. Sci. Eng. Technol. 2010, 6, 98-103. [CrossRef]

53. Bukkarapu, K.R.; Rahul, T.S.; Kundla, S.; Vardhan, G.V. Effects of blending on the properties of diesel and palm biodiesel. In IOP Conference Series: Materials Science and Engineering; IOP Publishing Ltd.: Hyderabad, India, 2018; Volume 330, pp. 1-15. [CrossRef]

54. Yao, C.; Dou, Z.; Wang, B.; Liu, M.; Lu, H.; Feng, J.; Feng, L. Experimental study of the effect of heavy aromatics on the characteristics of combustion and ultrafine particle in DISI engine. Fuel 2017, 203, $290-297$. [CrossRef]

55. Phan, A.N.; Phan, T.M. Biodiesel production from waste cooking oils. Fuel 2008, 87, 3490-3496. [CrossRef]

56. Chen, H.; Xie, B.; Ma, J.; Chen, Y. NOx emission of biodiesel compared to diesel: Higher or lower? Appl. Therm. Eng. 2018, 137, 584-593. [CrossRef]

57. Giakoumis, E.G.; Sarakatsanis, C.K. A comparative assessment of biodiesel cetane number predictive correlations based on fatty acid composition. Energies 2019, 12, 422. [CrossRef]

58. de Oliveira, F.M.; de Carvalho, L.S.; Teixeira, L.S.; Fontes, C.H.; Lima, K.M.; Câmara, A.B.; Sales, R.V. Predicting cetane index, flash point, and content sulfur of diesel-biodiesel blend using an artificial neural network model. Energy Fuels 2017, 31, 3913-3920. [CrossRef]

59. Bemani, A.; Xiong, Q.; Baghban, A.; Habibzadeh, S.; Mohammadi, A.H.; Doranehgard, M.H. Modeling of cetane number of biodiesel from fatty acid methyl ester (FAME) information using GA-, PSO-, and HGAPSO-LSSVM models. Renew. Energy 2020, 150, 924-934. [CrossRef]

60. Mishra, S.; Anand, K.; Mehta, P.S. Predicting the cetane number of biodiesel fuels from their fatty acid methyl ester composition. Energy Fuels 2016, 30, 10425-10434. [CrossRef]

61. Moser, B.R. Biodiesel production, Properties and Feedstocks. In Biofuels; Springer: Singapore, 2011; pp. 285-347.

62. Giakoumis, E.G.; Sarakatsanis, C.K. Estimation of biodiesel cetane number, density, kinematic viscosity and heating values from its fatty acid weight composition. Fuel 2018, 222, 574-585. [CrossRef]

(C) 2020 by the authors. Licensee MDPI, Basel, Switzerland. This article is an open access article distributed under the terms and conditions of the Creative Commons Attribution (CC BY) license (http://creativecommons.org/licenses/by/4.0/). 